\title{
A Conceptual Framework for Mitigating Graduate Employment Problems
}

\author{
Kerangka Kerja Konsep untuk Pengurangan Masalah Pekerjaan Graduan
}

\author{
Amer Al Nejam ${ }^{1}$, Alicia Tang Yee Chong ${ }^{2}$, Mohd Sharifuddin Ahmed ${ }^{2}$, \\ Osama Al-Masri ${ }^{1}$ \\ ${ }^{1}$ College of Computer Science and Information Technology, Universiti Tenaga Nasional; \{aamernjm, \\ osama.almasri1987\}@hotmail.com \\ ${ }^{2}$ College of Computer Science and Information Technology, Universiti Tenaga Nasional; \{aliciat, sharif\}@uniten.edu.my
}

\begin{abstract}
Graduate employability has always been an issue of concern when prospective employers complain of the lack of prerequisite attributes of fresh graduates. Despite the many efforts to ease the problems, graduate employment issues continue to plague Malaysia's labor market. We attest the veracity of this remark by the continued and prolonged social issues, as consequences of these problems, faced by many parties including government agencies, higher learning institutions, industries, parents and unemployed graduates themselves. Higher learning institutions and industries are often at odds when it comes to graduate's quality. Parents and their unemployed children present another social problem. In our contribution to mitigate these issues, this paper proposes a conceptual framework which involves the main stakeholders related to the graduate employment issues. The cooperation between these stakeholders is key to the successful implementation of the framework that mitigates the graduate employment problems.
\end{abstract}

Keywords: Mitigating graduate employment problems, higher learninig institutions, conceptual framework.

\begin{abstract}
Abstrak
Kebolehpasaran graduan sentiasa menjadi satu isu apabila majikan mengadu graduan mempunyai kekurangan ciri asas. Dengan pelbagai usaha untuk menangani masalah ini, isu kebolehpasaran graduan secara berterusan mengganggu pasaran pekerjaan di Malaysia. Kami membuktikan kebenaran kenyataan isu sosial yang berpanjangan ini, serta kesan terhadap pemasalahan ini, dihadapi oleh pelbagai pihak termasuklah agensi kerajaan, institusi pengajian tinggi, industri, ibu bapa dan graduan sendiri. Institusi pengajian tinggi dan industri sering berbalah berkaitan dengan kualiti seorang graduan. Ibu bapa dan graduan yang masih menganggur menimbulkan masalah sosial berlanjutan. Sebagai sumbangan kami dalam mengatasi masalah ini, artikel ini mencadangkan kerangka kerja konsep yang melibatkan pihak berkepentingan utama yang berkaitan dengan isu kebolehpasaran graduan. Kerjasama antara pelbagai pihak berkepentingan ini adalah kunci kepada keberhasilan pelaksanaan kerangka kerja yang dilihat mampu mengurangkan masalah pekerjaan graduan.
\end{abstract}

Kata kunci: Pengurangan masalah pekerjaan graduan, institusi pengajian tinggi, kerangka kerja konsep. 


\section{INTRODUCTION}

Graduate employment (or unemployment) is a long-standing issue that needs to be objectively and cooperatively resolved or mitigated. Along with this problem, there are other related issues that require equal attention and resolution. These include:

- Students taking programs that are mismatched with their interests.

- Educational programs that produce graduates that mismatch the needs of industries (e.g., too many Social Science graduates when the country needs more Engineering graduates).

- Graduates holding positions that are mismatched with their qualifications, (e.g., a Chemistry graduate holding an Office Administrator post).

- Graduates holding positions that are lower than their qualifications (e.g. an Engineering graduate holding a technician post).

While many efforts have been made to resolve these issues, graduate employment problems continue to plague Malaysia's labour market. We attest the veracity of this remark by the continued and prolonged social issues, as consequences of these problems, faced by many parties including government agencies, higher learning institutions, industries, parents and unemployed graduates themselves. Higher learning institutions and industries are often at odds when it comes to graduate's quality. Parents and their unemployed children present another social problem. We cannot ignore the fact that these unemployment issues and the related problems originate since entry level students enrolled in a myriad of degree level programs offered by higher education institutions. Social dynamics, economic conditions and financial issues are some major a priori factors that determine the selection of these programs by these entry level students. Other factors determine their successes and failures in completing their academic programs. Consequently, we embark upon a study to mitigate these issues from the entry-level end of the educational process with the following objectives in mind:

- To investigate and determine the main factors that are considered to be the causes of graduate employment problems.

- To identify the sources of information and knowledge that lead to potential solutions to the problems.

- To propose a conceptual framework that exploits the factors and the information in mitigating the severity of the problems.

This paper presents the work-in-progress of our research in mitigating issues of graduate unemployment. We organize the paper as follows: Section 2 reviews the literature on the issues of graduate employment. Section 3 discusses the development of a conceptual framework and Section 4 concludes the paper 


\section{LITERATURE REVIEW}

A total of 184,581 students graduated in 2011 and 44,391 or $24 \%$ of these graduates, mostly bachelor's degree holders, were unemployed (Sieng Lai, 2011; AfterSchool.my, 2014). In July 2013, The Star (online) reported that up to $40 \%$ of public university graduates in Malaysia are either jobless or are stuck in mismatched occupations. Between $30 \%$ and $40 \%$ of graduates are unable to find jobs after completing their university studies or are stuck with disciplines that do not match with their qualifications. Generally, graduates are blamed for not having the required skills upon graduation such as entrepreneurial, social, and soft skills (Altbeker \& Storme, 2013). Poor communication skills in English, wrong work attitude, unrealistic expectations are frequently cited by employers in turning down graduates for employment, and mainly mismatched major of study with the students' interests (Ismail, 2011; AfterSchool.my, 2014).

Apparently, the graduate employment problem is a global issue (Elaine, 2009; Ministry of Higher Education, 2012; Jones \& Ph, 2014). Our general review indicates some countries, e.g. United States, Europe and China face similar problems, South Africa seems to be lacking in graduates (Jones \& $\mathrm{Ph}$, 2014). In Europe, Elaine and Moisander (2009, 2013) deliberated on the opinions of stakeholders on this issue. She quoted the common opinions that there is a mismatch between skills and labor market demands and that there is an oversupply of graduates for certain fields. She suggested that the root causes of graduate unemployment need to be further investigated and understood, as they extend beyond the content or quality of education.

In China, according to China's Ministry of Human Resources and Social Security, the number of jobs in the country declined 7\% since October 2008. China also experiences a glut of graduates in accounting, law, art, literature and computer science. There are too many applicants for positions in these fields but yet many companies still lack qualified employees working in specialized or technical fields (Ministry of Higher Education, 2012).

In Malaysia, the Ministry of Education (MoE) in its effort to mitigate the problems has produced the National Graduate Employability Blueprint 2012-2017 outlining the strategies and actions to improve graduate employability. The blueprint charter service for four primary purposes in order to produce an employable talent pool in Malaysia (The Star Online, 2014), which are as follows:

- To support the role of Higher Education (HE) in building Malaysian's human capital stock.

- To suggest that Institution of Higher Learning (IHL) must provide the local talents with opportunities to live their career dreams.

- To enable IHL to design better curricula embedded with core competencies.

- To emphasize the achievement of sustainable employability for IHL graduates.

The blueprint defines employability as the potential to secure, maintain, and grow in a particular job at a workplace (Moisander, 2013; The Star Online, 2014). Employability is also about adopting the 
concept of life-long learning and processing the sets of attributes and skills that match those required by industry. Employment, on the other hand, is defined as a potential to secure a job at a workplace. While the blueprint stipulates overarching processes to address the graduate unemployment issues, the issues are still afflicting the nation and prick the conscience of every responsible party.

\section{THE DEVELOPMENT OF A CONCEPTUAL FRAMEWORK}

We develop a conceptual framework via analyzing the entry level conditions that entail the students and their associated entities, namely their parents, qualifications, and characters. Based on our experience and a priori knowledge, we postulate that there are three types of entry-level students: Leaders, Followers and Doubters. They are defined as follows:

Leaders: These are students who are highly confident about their careers, their capabilities, what they want to be and what academic programs they should take. They are not easily influenced by their parents, seniors or peers. The risk of failing their academic programs is presumably low and skills and knowledge gained for employment are judged to be high.

Followers: While these types of students know their capabilities, they are not quite confident about what they want to be and usually follow their parents and/or peers in selecting and taking up academic programs. The risk of failure is presumably moderate, while the skills and knowledge gained for employment could range from moderate to high.

Doubters: These are students who have no confident about their careers, doubtful about their capabilities and indifferent to what academic programs are suitable for them. The risk of failure is high while the skills and knowledge gained for employment are judged to be low.

We propose to develop a Streaming Profiler which is an algorithm that classifies and streams each student according to their interests, natural capabilities and traits that would be useful for employment. These profiles are stored in a Profile Database. The input to the profiler, which are the interests, natural capabilities and traits are obtainable via the mix-method approach that solicits data from foundation and matriculation students as shown in Figure 1. 


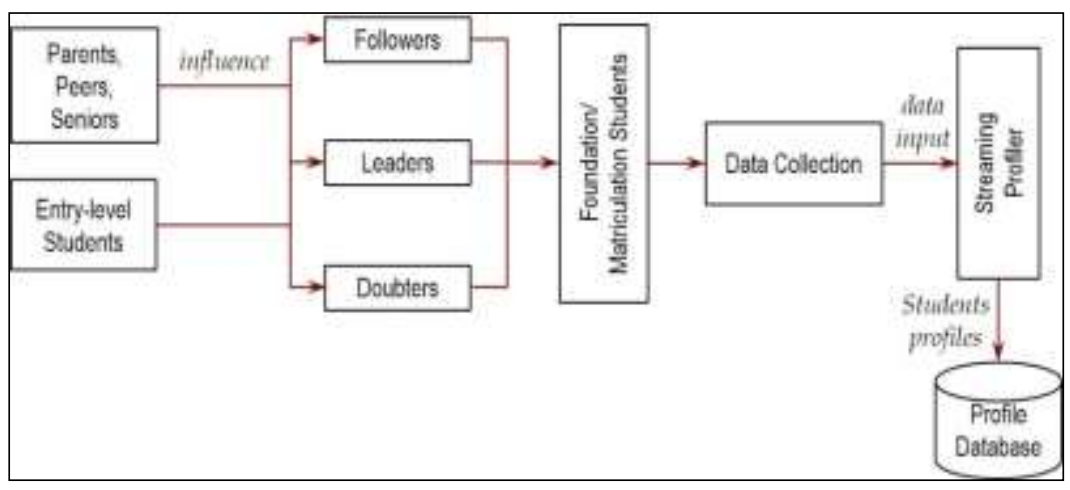

Figure 1: Profiling entry-level students.

We then focus on contributions of higher education institutions (HEI) as the producers of academic programs and industries as the hirers of graduates. To a certain extent, academic programs are designed based on the needs of the nation. Each year, many numbers of entry-level students enroll in these programs without considering:

- their interests and natural capabilities that match the programs' outcomes,

- whether their numbers match the needs of a particular industry.

Due to these non-considerations, HEIs generate graduates 'blindly' hoping that the graduates' skills and qualifications and their numbers match the needs of the industries. However, graduate unemployment and the related problems indicate that these are not the case. We attempt to resolve these issues via two algorithmic techniques in identifying and offering needed academic programs and their corresponding number of graduates for the industries as follows:

Student Profile-Program Matching Algorithm: This algorithm matches the students' profiles with the academic programs offered by the HEIs. Parameters from both data (profiles and programs) are analyzed and computed to determine the best possible match thus reducing the risk of failures and improved students' skills and knowledge gained for employment. The output of this algorithm is matches of students' profiles (who) with (what) academic programs.

Program-Position Matching Algorithm: It is required that Industries (public and private sectors) which need graduates with the right skills and knowledge enter their projected human resources' needs as positions' specifications into a Positions Specifications Database. An important parameter is the number of graduates required for a particular position. Hence, the number of graduates derived from each record determines the total (cumulative) numbers of graduates required to fill the corresponding positions. A cumulative number is obtained by counting the number of positions entered in the 
database and offered by all participating organizations (public or private) for one particular position. Due to an inherent lag in the academic process (3-4 years), projected or forecasted data is entered for a particular enrollment year. The algorithm works by matching the projected positions with the academic programs and analyzing and computing the relevant parameters of both data. The output of this algorithm is (what) academic programs and the number (how many) of graduates that are required to fill the positions. Figure 2 show the complete conceptual framework for mitigating graduate employment problems.

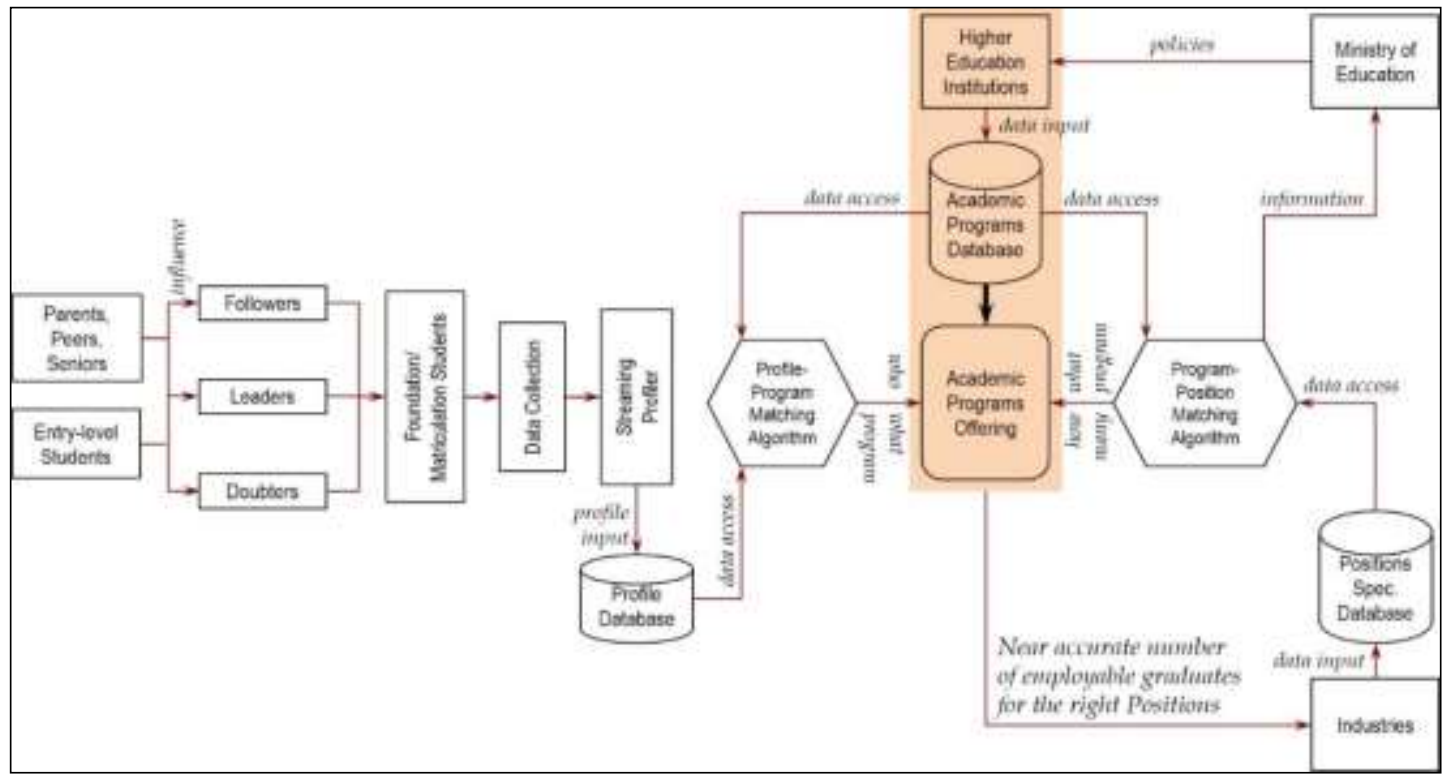

Figure 2: The conceptual framework for mitigating graduate employment problems.

The Ministry of Education (MoE) is the primary stakeholder in this framework. Information from the systems developed in the framework is readily accessible by the Ministry. The information is used to generate policies pertaining to the implementation of the framework.

\section{CONCLUSION AND FURTHER WORKS}

The outcome of the framework would lessen the problems of graduate employment and its related issues. Its outcome is a near accurate number of employable graduates for the right positions in the relevant industries. The outcome would mitigate the following problems:

- Students taking programs that are mismatched with their interests - this would be mitigated by matching students' profiles with academic programs. 
- Educational programs that produce graduates that mismatch the needs of industries - this would be mitigated by matching the number of positions with academic programs.

- Graduates holding positions that are mismatched with their qualifications - this would be mitigated by matching students' profiles with academic programs and by matching the number of positions with academic programs.

- Graduates holding positions that are lower than their qualifications - this would be mitigated by matching the number of positions with academic programs.

The research entails the further works of developing the Streaming Profiler for entry-level students, the Student Profile-Program Matching Algorithm, the Program-Position Matching Algorithm and the tools for data and information elicitation from Students, Higher Education Institutions and Industries.

When the framework is successfully implemented, a further improvement on the system could be made by deploying a multi-agent system for improved intelligence. Agent-based platforms are suitable due to the distributed nature of the system (Al-Masri \& Ahmad, 2017).

\section{ACKNOWLEDGEMENTS}

I would like to thank Universiti Pendidikan Sultan Idris for offering me the opportunity to publish my research; also, I would like to thanks my supervisor Prof. Dr. Mohd Sharifuddin Ahmad for his continuous and unlimited support.

\section{REFERENCES}

AfterSchool.my, http://afterschool.my/news_details.php?nid=323. Accessed 27-2-2014.

Al-Masri, O. H., \& Ahmad M. S. (2017). A conceptual framework for a problem resolution support system (PReSS). Journal of Advances in Information Technology, 8(2), 148-153.

Altbeker, A., \& Storme, E. (2013). Graduate unemployment in South Africa: A much exaggerated problem. Centre for Development and Business and Social Science, 2(16).

Elaine Wu, China's Graduate Problem, June 2009. Enterprise. http://www.thestar.com.my/News/Community/2013/07/27/. Accessed 27-2-2014.

Ismail, N. A. (2011). Graduates' characteristics and unemployment: A study among Malaysian graduates. International Journal of Business and Social Science, 2(16).

Jones, L. K., \& Ph, D. (2014). Choosing a college major based on your personality: What does the research say?, 4-8.

Ministry of Higher Education (2012). The National Graduate Employability Blueprint 2012-2017, Putrajaya.

Moisander, T. (2013). Graduate unemployment-Whose fault is it?-University World News. The University World News, (268). Science, Economics and Art, 1(1), 15-18.

Sieng Lai, W. (2011). Unemployment among Graduates: Study of Employers Perception on Graduates. Proceeding of the International Conference on Social Science, Economics and Art 2011, 15-18.

The Star Online, Published: Saturday July 27, 2013. Updated: Saturday July 27, 2013. 